can approach to the universal problems of governing with those of other nations. Most of the 1997 participants came from countries which have changed either from singleparty communist or military rule to fledgling democracies within the past decade. The American experience of over 200 years under the same constitutional form of government provides a sharp contrast with their experiences in their homelands.

Throughout the institute we tried to mix contemporary political science scholarship (including the latest teaching materials on American governments) with direct contact with the practitioners of government and politics at all three levels. Most of the faculty in the SIUC Department of Political Science, as well as a number of faculty from other departments in the College of Liberal Arts and School of Law, participated. And this year we were able to add two members of the staff of the new SIU Public Policy Instituteformer U.S. Senator Paul Simon and former Press Secretary to Governor Jim Edgar Mike Lawrence to our program.

Classroom time was supplemented with one week long trip to the Illinois state capital in Springfield and a variety of sites in Chicago and a second one week trip to Washington, D.C.

\section{Harvard University Library and APSA Launch PROceedings}

Selected scholarly papers from the 1997 APSA Annual Meeting are now available on-line through PROceedings: Political Research Online. Currently in a concept demonstration phase, PROceedings will offer the papers free of charge through August 1998. The PROceedings web site is located at

http://PRO.harvard.edu/

The PROceedings project aims to disseminate political science research more broadly and directly, to continue the scholarly exchange of the annual meetings beyond their settings, to encourage the instructional use of recent research, to support the process of peer review for scholarly journals, and to facilitate individual and library access to the annual meeting papers.

Authors from fourteen of the 1997 Annual Meeting's divisions submitted their papers to William J. Ball of The College of New Jersey, the director and primary administrator of the pilot project, who converted the papers to Portable Document Format and placed them on the project web site at Harvard University Library.

PROceedings features research papers from numerous subfields of political science. Papers can be accessed by browsing relevant portions of the annual meeting program or by searching extended abstracts. Users are welcome to view or print the papers, and to use them in ways consistent with the Association's copyright.

PROceedings is a collaborative project of the APSA and Harvard University Library. In addition to Ball the project director other principals involved include Sheilah Mann of the APSA and Sidney Verba and Dale Flecker of the Harvard University Library.

A demonstration of the PROceedings project was featured at the APSA booth during the Association's 1997 Annual Meeting in Washington.

\title{
Committee Suggestions Welcomed
}

The APSA welcomes suggestions for individuals interested in serving on APSA standing committees for terms beginning January 1, 1999. Appointments vary from one to three years and include award committees, PS Editorial Board, and a host of others. A listing of committees and their area of responsibility can be found in the March 1997 issue of PS. These positions are held on a volunteer basis. Interested members should make their suggestions by mail to President-Elect Matthew Holden, c/o the National Office at 1527 New Hampshire Ave., NW, Washington, DC 20036 or by email to nominations@apsanet.org.

\section{Conference Weighs Adjuncts' Impact}

Six APSA representatives participated in a conference on the use of part-time and adjunct faculty throughout the weekend of September 26 in Washington, D.C. Attendees included David Adamany of Wayne State University, Robert Dudley of George Mason University, Milton Greenberg of American University, Charles Harris of Howard University, Catherine Rudder of APSA, and Toni-Michele Travis of George Mason University.

Initiated by the American Historical Association, the conference was co-sponsored by AHA, APSA, and several other scholarly organizations and the American Association of University Professors. Representatives of these organizations and others offered the perspectives of graduate students, adjunct and part-time professors, full time faculty, administrators, union organizers, and scholars of and leaders in higher education.

Adamany, outgoing President of Wayne State, prepared a paper for the conference to make the case for the value of part-time faculty and served on one of the panels at the meeting. In his presentation he listed a series of characteristics of an industry-such as costs of service consistently exceeding the inflation rate, independence of practitioners, and apparent lack of external accountability-and challenged the audience to identify what enterprise he was referencing. Though higher education was the likely guess, to the contrary, Adamany averred that he was referring to the health care industry. His admonition, consistent with that of several other observers of trends in postsecondary education at the meeting, was that to be complacent was to be complicit in impending changes that could be anathema to academics.

Other speakers lamented the use of part-time faculty as simply a substitute for cheap labor and a way to avoid the tenure system. It was recognized, however, that part-timers can add flexibility, specialized knowledge, and fresh perspectives to an institution. Moreover, full-time faculty often prefer that part-time em- 
ployees be hired to teach lower division courses. At many institutions, faculty are misappropriated such that, as student preferences change, one school within an institution may have a disproportionately large number of full-time, tenure-track scholars and another with many more students may have too few faculty.

Both administrators and tenure track faculty do, it seems, have some control over the use of part timers, including how those nontenure-track faculty are treated. Conferees who had been part-time teachers, recounted experiences of being considered second-class citizens, virtually ignored by the full-time faculty.

Various papers made it clear that the disciplines varied in the degree to which part-time faculty are used and in the apparent need for such contingent workers. A major drawback of having a large group of such employees is that students can go through four or five years of college and can have taken few courses from the regular faculty, have no ongoing relationships with them, and have no one who knows their work sufficiently to write a knowledgeable letter of recommendation on their behalf.

Research presented by a variety of scholars pointed to some important facts concerning the use of part-time and nontenure-track faculty, including the following:

-About one-half of part-time faculty prefer to work part-time, while the other half would like full-time, tenure-track positions but can not find them.

-The proportion of part-time faculty at all postsecondary, academic institutions has increased from $22 \%$ in 1970 to more than $40 \%$ in 1993.

-The greatest use of part-time faculty is in community colleges. The proportion of faculty in community colleges increased from $19 \%$ in 1970 to $32 \%$ in 1993 , and $64 \%$ of community college faculty hold part-time appointments.

-Part-time employees are less likely to hold doctoral degrees.

-Part-time faculty report spending substantially less time on class preparation and out-of-class interaction with students and are less likely to publish than full-time faculty.

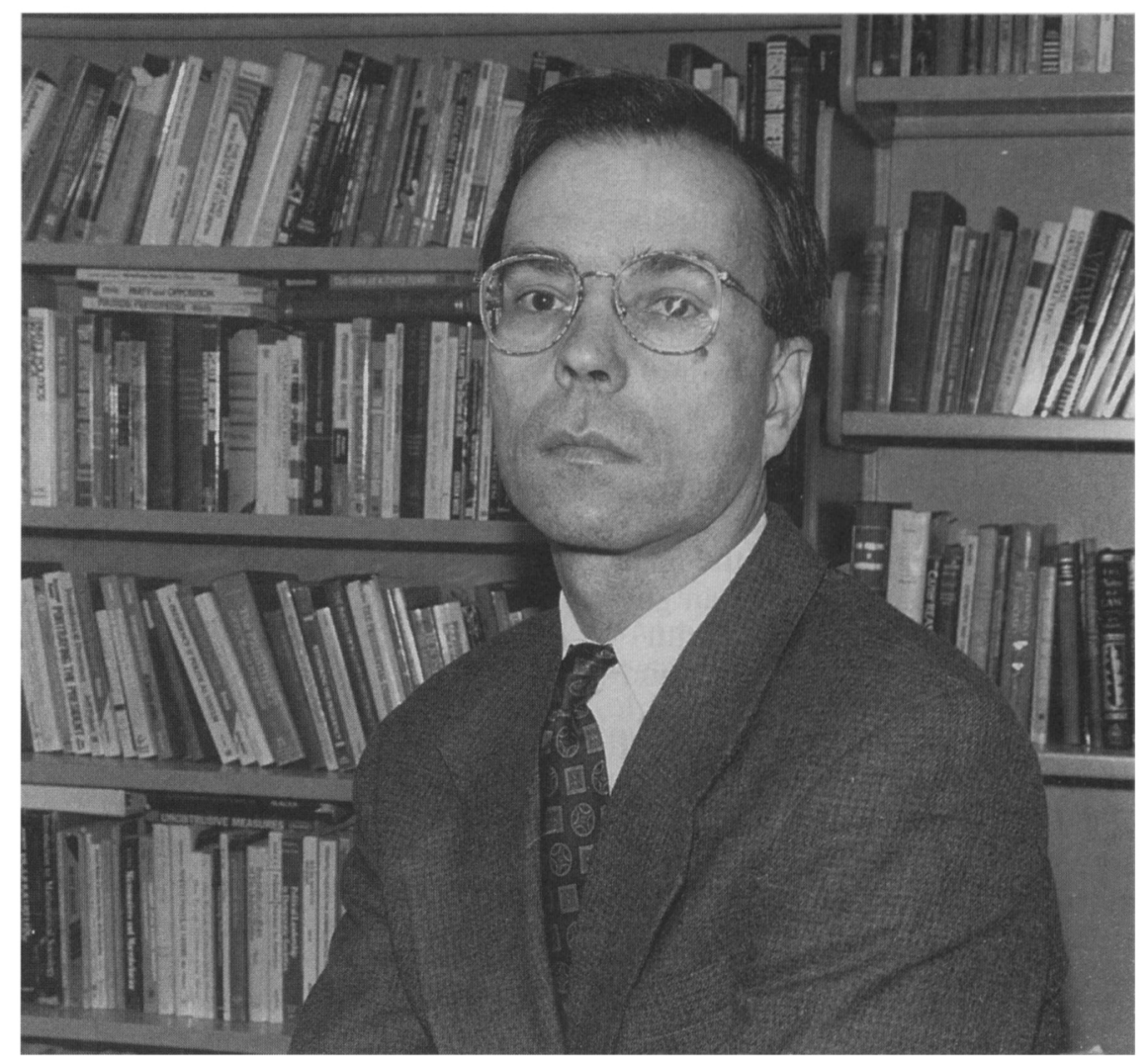

Gregory A. Calderia

- Part-time faculty receive much lower pay, fewer benefits, and less institutional support (such as offices and computer access) than their full time counterparts.

- Among Ph.D. faculty at Ph.D. granting institutions, the proportion of tenure-track faculty has declined from $85 \%$ in 1981 to $75 \%$ in 1975.

-Among Ph.D. faculty at M.A. granting institutions, the proportion of tenure-track faculty has declined from $90 \%$ in 1981 to $87 \%$ in 1995.

-One study of community colleges estimated that a teaching load which would require $\$ 35,000$ to $\$ 40,000$ for a full-time appointment would cost only $\$ 15,000$ if taught by several part-time faculty.

On the last day of the meeting, the conferees agreed on a draft statement that will be edited by a drafting committee and distributed to scholarly societies for further consideration. The report will be published in a future issue of $P S$ and will be presented to APSA's Council for possible action.

\section{Calderia Named AJPS Editor}

Gregory A. Calderia, professor of political science at Ohio State University will assume duties as Editor of the American Journal of Political Science on January 1, 1998. Midwest Political Science Association President Arlene Saxonhouse, University of Michigan, made the announcement at the Midwest annual meeting in April. Calderia replaces Kenneth Meier of the University of Wisconsin, Milwaukee, who has held the position since 1994. Calderia's appointment will run through 2001 . Beginning on January 1, manuscripts for the AJPS should be sent to: Gregory Calderia, American Joumal of Political Science, Department of Political Science, Ohio State University, 2140 N. Derby Hall, 154 North Oval Mall, Columbus, OH 43210. 